\title{
DEVELOPING INTERACTIVE MULTIMEDIA FOR TEACHING DESCRIPTIVE TEXTS BASED ON PALEMBANG LOCAL CULTURE
}

\author{
Ria Elviana \\ Department of English Language Education, Faculty of Teacher Training and Education \\ Sriwijaya University, Indonesia \\ Email: riaelviana@ymail.com \\ Rita Inderawati \\ Department of English Language Education, Faculty of Teacher Training and Education, \\ Sriwijaya University, Indonesia \\ Email: ritarudisaid@yahoo.com \\ Soni Mirizon \\ Department of English Language Education, Faculty of Teacher Training and Education, \\ Sriwijaya University, Indonesia \\ Email: smirizon@gmail.com
}

\begin{abstract}
APA Citation: Elviana, R., Inderawati, R., \& Mirizon, S. (2020). Developing interactive multimedia for teaching descriptive texts based on Palembang local culture. Indonesian EFL Journal, 6(1), 19-26. doi: 10.25134/ieflj.v6il.2634.
\end{abstract}

Received: 14-02-2019

Accepted: 23-04-2019

Published: 01-01-2020

\begin{abstract}
The purpose of this study was to find out the validity, practicality, and potential effect of the developed interactive multimedia for teaching descriptive texts based on Palembang local culture. With Research and Development (R\&D) study, this research procedure was adapted from ADDIE model consisted of five phases, i.e. analysis, design, development, implementation, and evaluation. In evaluation phase, formative evaluation which consisted of self-evaluation, expert review, one to one evaluation, small group evaluation, and field test. Formative evaluation was conducted to see the validity, practicality, and potential effect of the product. Validity was evaluated in expert review phase for its content, construct, and media. Based on experts review the result showed that the average score of all aspects of the developed product was 3.58 which can be categorized as very highly valid. The practicality was evaluated in one to one evaluation and small group evaluation. The result showed that the product was very highly practical since the average score in both phases were 3.69 and 3.74 respectively. The potential effect was evaluated in the field test. The product also had very high potential effect after being tried out in the field test as $100 \%$ of the students achieved the minimum mastery criterion which was 75 . In conclusion, the developed product was potentially effective to be applied for the tenth grade students.

Keywords: development research; interactive multimedia; descriptive texts; Palembang local culture.
\end{abstract}

\section{INTRODUCTION}

In the teaching and learning process, teachers can use media to support the process. To accommodate a variety of student learning styles, a teacher can combine it through multimedia. Multimedia is an integration of many types of media on a single medium in the same information unit (Thamarana, 2017). One way to develop multimedia to be innovative is by using interactive multimedia. Interactive multimedia is digital system where multiple media or people have an effect on each other through their interactive behavior (Delliyannis, 2012).

The teacher needs to consider that interactive multimedia has advantage in the teaching and learning process. The use of interactive multimedia makes student retain more information than other media. It is proved by Leow and Neo (2014) showed that there was 83.9 $\%$ of students had motivated to learn interactive multimedia and $93.5 \%$ of students had individualized learning in exploring more knowledge. It means that interactive multimedia gives high motivation and chance to use higher order thinking skills (HOTS) in teaching and learning process. Higher order thinking skills (HOTS) was designed with six levels in Bloom Taxonomy. The six levels were remembering, understanding, applying, analyzing, evaluating and creating. Therefore, interactive multimedia is needed as the media for teaching and learning process in the class.

English in senior high school is taught in grades X, XI, and XII. There are four skills that 
should be taught in all grades, one of them is reading. Ideally, all of those skills have to be taught as an integration. Reading is one of the four major skills considered as the most important in learning English (Carrel, 1998). Moreover, it is an essential skill which helps students widen and deepen their knowledge of the language. If we have good reading skill, we can comprehend the meaning or the content of the text easily. Comprehending the implicit information desires an effort. So, reading comprehension is not as simple as it is assumed. Reading comprehension has been the skill that is more emphasized in foreign language teaching.

Concerning this, the results of some studies showed the facts that reading comprehension is an issue in Indonesia. For example, Indonesia is known as unsatisfactory rank in reading comprehension. OECD/PISA (2015) reported that the reading ability of Indonesia students was low than in other countries. According to PISA 2015 database, Indonesian score in reading achievement was below the OECD average and puts Indonesia in $62^{\text {nd }}$ place out of 70 countries. The student's ability score on the overall reading scale was 403 while the OECD average score was 493. The data clearly reveal that adolescent's reading literacy in Indonesia still poor compared to those of other countries.

There are some factors that influence success in reading comprehension. Jayanti (2016) found that the cause of low reading achievement among students is varied such as reading anxiety, reading engagement, reading enjoyment, attitude, behavior and reading resources or materials contribute to reading achievement. Based on the facts, the teacher must develop reading material to solve these problems. Another concern which needs to be addressed was that the teacher has to consider the cultural aspect of teaching English. The objective of teaching English as stated in the national curriculum is achieving communicative competence. To achieve communicative competence, culture is the basis of communication since the meaning conveyed in the language used depends on a society where they live and the communication is delivered through language. In other words, teaching language is never done without culture.

Supporting this idea, the Indonesian government already supports the implementation of local culture material in education. It is establishing the Minister of Education and Cultures Regulation No 22 and 23/2006. In this act, the government gives a big chance for local culture to being integrated on various school subject either in the curriculum of primary or secondary education.

Despite the fact that teaching English is inseparable with teaching its culture, it does not mean that local culture is neglected and not included in ELT materials. Local culture is highlighted. Pauzan, Joko, Hartono, et al (2017) state that the uniformity of the materials somehow ignores the local content where the learning occurs and where the students feel engaged with the materials as it is part of their life. Thus, an attempt at preserving local culture is important in the middle of this globalization era.

In 2013 Curriculum, descriptive text as stated in Basic Competence point 3.4 and. 4.4, is one kind of genres that will be learned at the tenth grade of senior high school students. In the teaching descriptive text, the writer applied a method of developing materials for this genre. Wardani, Basri, and Waris (2014) define that descriptive text is a text that gives information about a particular person, place, or thing. The descriptive text tells about how the characteristics of the subject or the detail description of something. Noprianto (2017) states that as nonfiction genre, descriptive text regarded important to be introduced to the young learners as soon as possible because it is clearly recognized that when students learn nonfiction genres and they actively engage with the world outside themselves.

Considering the need of local culture in teaching and learning process which are originally from Palembang are expected can be utilized effectively as reading material in EFL classroom. Palembang city is one of the famous places in Indonesia because of the variation of culture. Lussetyowati (2014) writes that Palembang is the center for the culture during the Sriwijaya Kingdom and Palembang sultanate until now. It means that Palembang has many cultural heritages so people can be interested in visiting Palembang. It is proved by BPS Palembang (2018) showed that the significant improvement of domestic and foreign tourists from January-June 2017 to January-June 2018. It can be seen from the increasing number of domestics or foreign tourists. The number of tourists who visited in Palembang in 2017 was 6.66 million tourists while in 2018 were 7.53 million tourists. It can be concluded that Palembang has many potential things for domestic or foreign tourists 
From the explanations above, it can be concluded that the aim of this study was to find out find out the validity, the practicality and potential effect of interactive multimedia for teaching descriptive text based on Palembang local culture for the tenth-grade students in SMA LTI IGM Palembang.

\section{METHOD}

This is Research and Development (R\&D) study. The research procedure was adapted from ADDIE model consisted of five phases, i.e. analysis, design, development, implementation, and evaluation. In evaluation phase, formative evaluation which consisted of self evaluation self evaluation, expert review, one to one evaluation, small group evaluation, and field test. This research conducted at SMA LTI IGM Palembang. The population of this study was the tenth-grade students consisting of four classes in academic year 2018/2019. The subjects of this study were described in Table 1.

Table 1. The subjects of the study

\begin{tabular}{|c|c|c|c|}
\hline No & $\begin{array}{l}\text { Stages of } \\
\text { Formative } \\
\text { Evaluation }\end{array}$ & $\begin{array}{c}\text { Number } \\
\text { of } \\
\text { Students }\end{array}$ & $\begin{array}{l}\text { Description of the } \\
\text { Students }\end{array}$ \\
\hline 1 & $\begin{array}{l}\text { One-to-one } \\
\text { evaluation }\end{array}$ & 3 & $\begin{array}{l}1 \text { student for each } \\
\text { category, i.e: low, } \\
\text { medium, and high } \\
\text { English } \\
\text { Proficiency }\end{array}$ \\
\hline 2 & $\begin{array}{l}\text { Small } \\
\text { Group }\end{array}$ & 9 & $\begin{array}{c}3 \text { students for } \\
\text { each category, } \\
\text { i.e: low, medium, } \\
\text { and high English } \\
\text { Proficiency }\end{array}$ \\
\hline \multirow[t]{2}{*}{3} & Field Test & 17 & $\begin{array}{l}\text { All students in a } \\
\text { real class }\end{array}$ \\
\hline & & TOTAL & 29 Students \\
\hline
\end{tabular}

The subjects of this study were selected based on purposive sampling. The subjects of this study had been classified by school based on the students' English proficiency which was level 1 for high level, level 2 for medium level, and level 3 for low level. So the writer only took the representative of students based on their level for each stage used the different class.

In collecting the data, the writer used questionnaire and reading comprehension test. For the data analysis, this study was used to determine its validity, practicality, and potential effect. The validity of the product was validated based on experts' judgment. After evaluating the product, the experts gave their comments or opinion through a questionnaire provided by the writer. Their comments were used as a basis for revision of the developed product. To determine the validity level of the product, the average score of the obtained total score from three experts' judgment related to the content, instructional design, and media. The data which collected tabulated and the result of each instrument was calculated and classified based on validity level.

While the potential effect of the product was determined by the result of field test. After the reading comprehension of product was conducted in field test, the writer analyzed the quality of the items of reading comprehension test result from 17 students participating in the field test by using item analysis. There are two items analysis to know the quality of the items of reading comprehension test result which were items difficulty index and items discrimination index

After the difficulty index and discrimination index had been done, the writer checked the potential effect of the product. The developed product can be said had potential effect if the students can be reached the minimum mastery criterion (KKM) that was 75 and the total percentage of the students who passed the KKM that was 75 .

\section{RESULTS AND DISCUSSION}

This is Research and Development (R\&D) study. The research procedure was adapted from ADDIE model consisted of five phases, i.e. analysis, design, development, implementation, and evaluation. In evaluation phase, formative evaluation which consisted of self evaluation self evaluation, expert review, one to one evaluation, small group evaluation, and field test. Formative evaluation was conducted to see the validity, practicality, and potential effect of the product.

\section{Analysis phase}

\section{Document and existing materials analysis}

In this analysis, the instructional design of tenth grade of SMA LTI IGM Palembang was analyzed in 2013 curriculum. From the analysis phase, the core competence and basic competence of descriptive text demanded students to response descriptive texts actively and established students become an active reader. In this case, the students were expected to able to determine social function, and identify text structure, language feature, and various meaning in the form descriptive text based on Palembang local culture. According to The Ministerial Regulation No. 65 of 2013 regarding standard process, learning goals in the curriculum 2013 cover students 
development in three aspects which are attitudes, knowledge, and skills.

The available reading material analysis of descriptive text was government books of tenth graders and a supplementary book entitled "English for SMA" published by Grafindo. From two books, the available materials descriptive text at level 8, 9, 10, and 13 after analyzed with readability tool (Flesh Kincaid online). There was also no material reading dealing with descriptive text based on Palembang local culture. Besides, the total number of descriptive texts available in the textbook was still insufficient. There were only three texts of descriptive text for each textbook.

\section{Students' need analysis}

In this study, there were 25 questions and there were 64 students who participated from all tenth grade students in answering the questionnaire from four classes. There were some aspects adapted from Dick, Carey, and Carey (2005) which were taken into consideration to information about students' needs. They were (1) their reading achievement; (2) the perception of learning process, (3) their barriers in reading comprehension; (4) their perception of the learning process; (5) their expectations on the developed reading materials, and (6) their expectations on the developed instructional media. From the students' need analysis, the results were: (1) students' reading skill was low but on the other side, the students agreed that having competence in reading English text was important; (2) students' interest in reading was low and it is shown by students' frequency in reading activity was seldom; (3) teacher of English used lecturing teaching method, and seldom even never used interactive multimedia; (4) students' eagerness in reading was high; (5) students' opinion in multiple choice was very high; (6) students' agreed that reading with electronic media was more interesting; (7) students never used interactive multimedia as learning media; (8) students knew a lot of Palembang local culture; (9) students agreed that reading material should have Palembang local culture because it was very important (10) students revealed that reading materials in the textbook were difficult to understand and were not suitable to students reading level.

\section{Students' reading level analysis}

The third analysis was to find out the students' reading level. Students' reading level analysis was determined by reading comprehension test result. The subjects of this study were 64 students from all the tenth grader. The reading comprehension test was taken from Jennings Informal Reading Assessment developed by Dr. Joyce. It was given to the students which included reading texts at level 4, 5, 6, 7, and 8 .

Table 2. The distribution of students' reading level

\begin{tabular}{|c|c|c|c|c|c|c|}
\hline \multirow{3}{*}{$\begin{array}{c}\text { Text } \\
\text { Level }\end{array}$} & \multicolumn{6}{|c|}{ Reading Stage } \\
\hline & \multicolumn{2}{|c|}{$\begin{array}{c}\text { Frustrational } \\
(\text { Correct } \\
\text { number } \leq 6)\end{array}$} & \multicolumn{2}{|c|}{$\begin{array}{c}\text { Instructional } \\
(\text { Correct } \\
\text { number } 7-8)\end{array}$} & \multicolumn{2}{|c|}{$\begin{array}{c}\text { Independe } \\
\text { nt } \\
\text { (Correct } \\
\text { number 9- } \\
10)\end{array}$} \\
\hline & $\mathrm{N}$ & $\%$ & $\mathrm{~N}$ & $\%$ & $\mathrm{~N}$ & $\%$ \\
\hline 4 & 26 & $\begin{array}{c}40.6 \\
\%\end{array}$ & 10 & $\begin{array}{l}15 . \\
6 \%\end{array}$ & 28 & $\begin{array}{l}43 . \\
7 \%\end{array}$ \\
\hline 5 & 27 & $\begin{array}{c}42.1 \\
\%\end{array}$ & 24 & $\begin{array}{l}37 . \\
5 \%\end{array}$ & 13 & $\begin{array}{l}20 . \\
3 \%\end{array}$ \\
\hline 6 & 30 & $\begin{array}{c}46.8 \\
\%\end{array}$ & 23 & $\begin{array}{l}35 . \\
9 \%\end{array}$ & 11 & $\begin{array}{l}17 . \\
1 \%\end{array}$ \\
\hline 7 & 13 & $\begin{array}{c}20.3 \\
\%\end{array}$ & 44 & $\begin{array}{l}68 . \\
7 \%\end{array}$ & 7 & 10. \\
\hline 8 & 35 & $\begin{array}{c}54.6 \\
\%\end{array}$ & 29 & $\begin{array}{l}45 . \\
3 \%\end{array}$ & 0 & $0 \%$ \\
\hline
\end{tabular}

From table distribution of students' reading level, it can be seen that students were at the independent stage ( $43.7 \%$ of 64 students) for text level 4. For text level 5, 6, and 8, students were at frustrational stage which was $(42.1 \%),(46.8 \%)$, and $(45.3 \%)$. While for text in level 7 , students were at the instructional stage (68.7\%). Therefore, it can be concluded that the students' reading level was at level 7 since the highest percentage of the instructional stage was in level 7. Azizi (2015) writes that readable text is crucial and play an important role in learning and teaching process. So, the teacher have to know matching the text with the students in order to encourage the students improve the reading skill

\section{Design phase}

In this phase, the first activity has collected the information from some sources about the Palembang local culture, arrangement, learning objectives, and relationship to the learning process. The writer took 40 reading texts as reading materials. After collecting the information the writer made a flowchart as the detailed outline. Based on the flowchart designed, the writer created a storyboard of multimedia. The storyboard can give an illustration of the screen layout for the multimedia. The storyboard is needed as guidance in developing materials of the product.

The second activity, in order to implement developed interactive multimedia in formative 
evaluation such as one to one, small group and field test, lesson plan guided the activities to find out the practicality and potential effect of the product. It is line with Kanellopoulou and Darra (2018) states that lesson plan identifies the process needed to meet the learning objective, the materials equipment needed, and the activity. The lesson plan was adapted from English subject basic competence 3.4 and 4.4 of tenth graders proposed by The Ministry of Education and Culture in curriculum 2013.

\section{Development phase}

In the development phase, this phase, the storyboard design of interactive multimedia was transformed into computer-based material by using Embarcadero Delphi Xe 2 program was created and launched in the form of software of interactive multimedia which could be run in every PC or notebook. UNESCO (2012) insists that the teacher need to initiate to use mobile technology in learning. Therefore, interactive multimedia is needed as the media for teaching and learning process in the class. Some result of computer-based materials is available in the appendix. It was called as prototype I. The interactive multimedia for teaching descriptive text based on Palembang local culture was made by a professional programmer. The programmer made product based on the direction and materials from the writer. The product had been done for one month in 11 meetings. The developed product was made by using storyboard into three categories of the screen layout design. Those three categories are described below:

First, home page is a starting screen of interactive multimedia. Home page design was a text displayed on the screen which was "Welcome to Interactive multimedia for learning descriptive text from Palembang Local Culture". A music background entitled "Gambus Palembang" was played. There were some pictures such as three pictures of Palembang local culture and Sriwijaya University logo. Besides, there was the name of the developer and the institution. To open the next page "Start" button was provided.

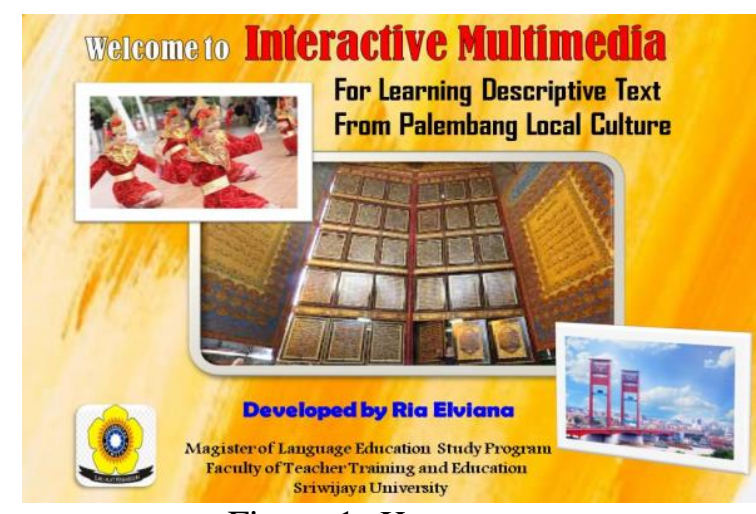

Figure 1. Home page

Second, after clicking the start button, then the introduction page appealing. There was a video about Palembang city and some of Palembang cultures such as Kemaro island, Gending Sriwijaya dance, and etc. A music background entitled "Ya Saman" song was played. It was one of the traditional song of Palembang.

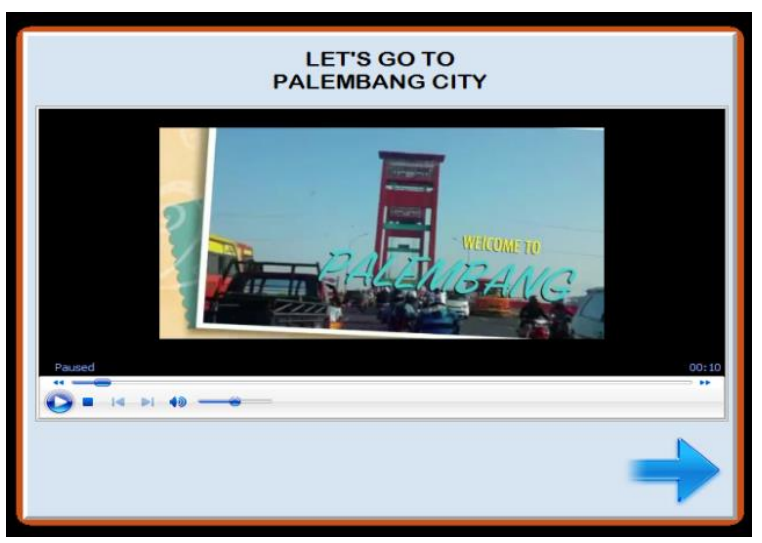

Figure 2. Introduction page

Third, the introduction page, the students are able to access the nest page which was "Main Menu". This main menu consisted of six buttons, they were the study page, the unit I, unit II, final test, users' guide, and developer. The further explanation about button was described as follow;

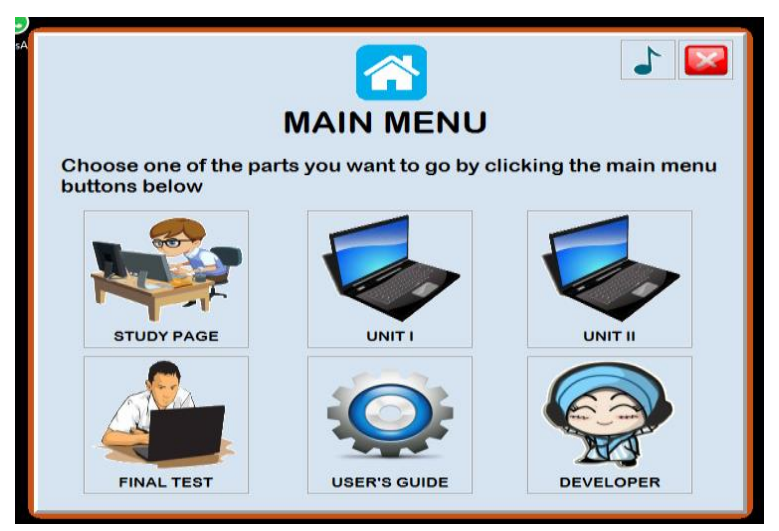

Figure 3. Main menu 


\section{Implementation phase Self evaluation}

At this evaluation, the writer evaluated the developed product from this self evaluation. The writer found some errors and shortcomings as functions of the navigation keys that are not in accordance with the hyperlink is desired, see an introduction page that was less interactive, the main menu, the choice of music, as well as some text typing wrong. From the findings of the writers to revise that prototype I was ready for validation by experts.

\section{Experts review}

A questionnaire was administrated to three experts in terms of content, instructional design, and media from 15 items questionnaires. A questionnaire was administrated to three experts in terms of content, instructional design, and media from 15 items questionnaires. In terms of content validity (i.e English), the expert reviewing the product was The dean of English FKIP in Tridinanti University Palembang. From the validation sheet, there were some suggestions which needed to be paid attention in content were (1) Adding some pictures in the cover background; (2) adding some text of Palembang local culture program in expertise in content. After reviewing the product, he stated that the product was valid with revision.

Then, in terms of construct validity (i.e instructional design), the expert reviewing the product was a lecturer of English study program and The Head of Language Institution in Sriwijaya University Palembang. From the validation sheet, there were some suggestions which needed to be considered (1) Adding Palembang's Song in the musical background of the product; (2) Time allocation for doing task should be considered. After reviewing the product, he stated that the product was valid with revision

The last, in terms of media, the expert reviewing the product was a lecturer of technology information in Bina Darma University Palembang. From the validation sheet, there were some suggestions which needed to be considered (1) The musical background of the product was turn off; (2) the arrangement of parts in unit I and I should change the position. After reviewing the product, he stated that the product was valid with revision

Based on the result of the validity of the product in terms of content, the obtained score was 3.47 which could be classified into very high validity. Then, in terms of construct, the obtain average score was 3.73 belonged to category very high validity. Next, in terms of media, the obtained average score was 3.53 which felt in very high validity level. The total average score got from three experts was 3.58. It can be concluded that the overall product had very high validity. To sum up, the developed interactive multimedia for teaching interactive multimedia based on Palembang local culture was valid with very high validity. The validity of the product should be free of bias to avoid inaccurate outcomes. Ernawati and Sukardiyono (2017) state that there were seven aspects in validating of media i.e. (1) subject matter, (2) auxiliary information, (3) affective consideration, (4) interface, (5) navigation, (6) pedagogy, and (7) robustness.

\section{One-to-one evaluation}

A questionnaire was administered to 3 students in one-to-one evaluation to determine the practicality of the product from the total 15 items of the questionnaire. The obtained score of practicality in one to one evaluation was 3.69 which was very high practical. The one to one evaluation was also intended to get comment toward the developed product which was (1) the students would be able to learn the product by using product independently at home; (2) the developed product was giving a new knowledge of Palembang local culture.

\section{Small group evaluation}

Then, the product that revised in the expert review and one to one evaluation stage was called as prototype 2 . The obtained score of practicality in small group evaluation was 3.74 which was very high practical. The small group evaluation was also intended to get comment toward the developed product which was (1) the students were interested and motivated to learn the developed product because it was very attractively; (2) The students' eagerness in learning developed product was high.

From both one to one evaluation and small group evaluation it can be concluded that developed product was "Very High Practicality" level It is caused by the development of the product was on the basis of the student's need. Sarjan and Mardiana (2014) claimed that student comprehension was supported by the content of reading deliver in the most appropriate format which was identified with the analysis of student reading need. In line with Leow and Neo (2014) who mentioned that their research had significant improvement when they found their students showed positive attitude change as they become 
more active and motivated in the learning process. The test results of their students showed the improvement of the students' learning achievement.

\section{Evaluation phase \\ Field test}

In the Evaluation phase, the field test was conducted in the real class of tenth-grade students of SMA LTI IGM Palembang with 17 students. The students participating in one to one evaluation and small group evaluation were not involved in this phase. After the reading comprehension of product was conducted in field test, the writer analyzed the quality of the items of reading comprehension test result from 17 students participating in the field test by using item analysis. Item analysis is useful helping teachers determine which items to keep, modify, or discard on a given test (Kleeman, 2018). There are two items analysis to know the quality of the items of reading comprehension test result. First, the writer measured the items difficulty index, there were 10 items considered as easy, 31 items considered as average, and 9 items considered as hard. The result of items difficulty index was the average score in $0.26-0.75$. It means that the reading comprehension text was good because the items were neither too difficult nor too easy. Second, for the discrimination index, the result showed that was a good score in more than 0.31. It is mean that most of the items were considered having positive discrimination. The findings indicated that items of reading comprehension test were matched with students reading ability. So the reading comprehension test was good to be tried out for the student.

Then, to determine the potential effect of the developed product, the writer measured the result of reading comprehension test of students who passed students criteria minimum mastery. From the result of the reading comprehension test. It showed that 17 students participating in field test reached scores above 75 . Since $100 \%$ of students passed the minimum mastery criterion, it can be concluded that the developed product had a potential effect. As mentioned by Farida, Yani and Sigit (2013) instructional reading would be effective or not after conducted an evaluation.

\section{CONCLUSION}

From the analysis, it can be concluded that the interactive multimedia for teaching descriptive texts based on Palembang local culture were valid with an average score of the validity was 3.67. It was indicated at high validity level. Then, the interactive multimedia was also practical after being evaluated in one-to-one evaluation with an average score (3.69) and small group evaluation with an average score (3.74). It was indicated at high practical level. Finally, interactive multimedia had a potential effect after being tried out in field test. It was determined by the result of students achievement in reading comprehension test since $84 \%$ of the students pass the minimum mastery criterion that was 75 .

Based on the findings of this study, some suggestions for teachers, students, schools and other researchers are offered. First, teachers are suggested to consider students reading level, students characteristics, and learning environment before teaching reading so the materials can match with students need. Second, the students are expected to read more and expand their reading competence. Third, the schools are suggested to provide the facilities for both teachers and students to implement ICT- based learning so that the learning is more effective, efficient, enjoyable and encourage teachers to use and develop their own instructional media. Finally, other researchers are suggested to develop other materials packaged in the form of ICT-based learning.

\section{REFERENCES}

Azizi, A. R. (2015). An analysis of the readability level of reading texts in passport to the world 2 textbook for second grade of junior high school. Jakarta: Syarif Hidayatullah State Islamic University.

BPS Palembang. (2018) Palembang dalam angka (Palembang in figure) tahun 2018. Retrieved from http://www.datin.menlh.go.id.

Carrel, P.D. (1998). Interactive approaches to second language reading $\left(7^{\text {th }}\right.$ ed). Cambridge, UK: Cambridge University Press.

Delliyanis, L. (2012). Interactive multimedia. Croatia: inTech Publishing.

Dick, W., Carey., \& Carey, J. O. (2005). The systematic design of instruction. $\left(6^{\text {th }} \mathrm{ed}\right)$. New York, NY: Pearson.

Ernawati, I., \& Sukardiyono, T. (2017). Uji kelayakan media pembelajaran interaktif pada mata pelajaran administrasi server. Electronics, Informatics, and Vocational Education) Journal, 2(2), 1-7.

Farida, I., Yani, D.E., \& Sigit, A. (2013). Analisis kualitas dan tingkat keterbacaan materi bahan ajar cetak melalui evaluasi formatif. Jurnal Pendidikan Terbuka dan Jarak Jauh, 14(2), 6978. 
Flesch Kincaid Reading Ease. (2019). Retrieved from http://www.Standards-schmandards. com/exhibits/rixindex.php.

Jayanti, F.G. (2016). Reading difficulties comparison on students' and teachers' perception. In Fernendita (Ed), International Seminar on Language and Teaching (ISELT-4). (pp 296-301). Bengkulu: Bengkulu University.

Jenning J.H., Caldwel, J. \& Lenner J. (2006) Jenning informal reading assessment in reading problems: Assessment and teaching strategies. $5^{\text {th }} \mathrm{ed}$. Available at: http://wps.ablongman.com/wps/media/objects/26 8pdf. (accessed 10 November 2018).

Kanellopoulou, E. M., \& Darra, M. (2018). The planning of teaching in the context of lesson study. International Journal of Education Studies, 11(2), 68-82.

Kleeman, J. (2018). Item analysis for beginners. Questionmark Conference. (pp 1-63). Savannah: Questionmark Corporation.

Leow, F. T., \& Neo, M. (2014). Interactive multimedia learning: Innovating classroom education in Malaysian university. The Turkish Online Journal of Education Technology, 13(2), 99-110.

Lussetyowati, T. (2014). Preservation and conservation through cultural heritage tourism. case study: Musi river side Palembang. Procedia Social and Behavioral Sciences, 184, 401-406.

Minister of Education and Cultures Regulation (Peraturan Menteri Pendidikan dan Kebudayaan No 65/2013). Standard accreditation Process for SMA. Retrieved from http://www.BSNP.go.id.

Minister of Education and Cultures Regulation (Peraturan Menteri Pendidikan dan Kebudayaan
No 22/23/2006). Pedoman penyusunan kurikulum tingkat satuan pendidikan jenjang pendidikan dasar dan menengah. Retrieved from http://www.BSNP.go.id.

Noprianto, E. (2017). Students descriptive text writing in EFL perspective. Indonesian Journal of English Language Teaching and Applied Linguistics, 2 (1), 65-81.

OECD. (2015) PISA 2015 result in focus. Retrieved from https://www.oecd.org/pisa/pisa-2015-resultin-focus.

Pauzan, J. N, Hartono, R. (2017). The teaching of local content subject of English for tourism in English language Learning at junior high school. International Journal of Innovative Science, Engineering \& Technology 4(4): (27-62).

Sarjan, N., \& Mardiana. (2014). An analysis on the English teachers strategies in teaching reading comprehension. English Language Teaching Journal, 17(2), 151-160.

Thamarana, S. (2017). Multimedia technologies in English language teaching: a study on English teachers. International Journal of English language, literature in humanities, 5(6), 526-555.

UNESCO. (2012). ICT in teacher education. Bangkok: Education Sector.

UNESCO. (2016). Preparing \& supporting teachers to meet the global challenges of $21^{\text {st }}$-century learning in Asia- Pacific. Bangkok: Education sector.

Wardani, I., Basri, H., Waris, A. (2014). Improving the ability in writing descriptive text through guidedquestion technique. Journal of English Language Teaching Society (ELTS). 2(1), 1-13. 